\title{
sciendo
}

DOI 10.2478/sbe-2020-0051

SBE no. 15(3) 2020

\section{CONSUMERS' PURCHASE INTENTIONS TOWARDS NOVEL DAIRY PRODUCTS: EVIDENCE FROM GREECE AND SERBIA}

\author{
MILIJEVIC SRDJAN \\ Perrotis College, American Farm School, Thessaloniki, Greece \\ SKLAVOUNOS NIKOLAOS \\ Perrotis College, American Farm School, Thessaloniki, Greece \\ ROTSIOS KONSTANTINOS \\ Perrotis College, American Farm School, Thessaloniki, Greece
}

\begin{abstract}
:
The aim of this paper is to investigate consumers' purchase intentions towards novel dairy products with evidence from Greece and Serbia. Based on the Theory of Planned Behavior (TPB) model, this research empirically tests a set of hypotheses concerning the consumers' purchase intentions towards novel dairy products. In addition to the dependent variable of purchase intention, the independent variables of food neophilia, product knowledge, health consciousness, social contacts and price perception are used for the development of hypotheses. A total of 288 usable questionnaires (144 from each country) were collected and analyzed. Finally, the empirical findings are discussed and managerial implications as well as recommendations for future research are presented.
\end{abstract}

Key words: Consumers' Purchase Intentions, Theory of Planned Behavior, Food Neophilia, Product Knowledge, Health Consciousness, Social Contacts, Price Perception.

\section{Introduction}

In recent years, academic research on consumer buying behavior of dairy products has increased (Tempesta \& Vecchiato, 2013; Cerjak \& Tomic, 2015; Samoggia, 2016; Rahnama \& Rajabpour, 2017). The dairy industry today faces numerous challenges and opportunities since consumers' preferences as well as environmental and ethical concerns continue to evolve. Dairy products and especially fluid milk have been traditionally regarded as healthy foods. Additionally, they are considered to contain numerous functional ingredients and materials that benefit human health such as energy, protein, carbohydrate, cholesterol, vitamin, riboflavin and calcium (Dror \& Allen, 2014; 
Jones et al., 2008; Sanders et al., 2009). According to Özer and Kirmaci (2010), they account for over $40 \%$ of total functional products. However, existing research has also documented some contradictory views regarding the effects of their consumption on human health. For example, they are regarded as a source of dietary fat, a view that may become more prevalent in the near future (Cash et al., 2005). Also, as noted in Thorning et al. (2016, p. 1), "Several media stories and organisations claim that dairy increases risk of chronic diseases including obesity, type 2 diabetes, cardiovascular disease, osteoporosis, and cancer".

Additionally, the production of dairy products requires significant resources and has an significant environmental impact. According to Gulland (2017), the production of meat and dairy foods is estimated to account for $14.5 \%$ of global emissions. Furthermore, Westhoek et al. (2014) state that the production and consumption of animal-based food products, including dairy, is widely acknowledged to have a negative impact on the environment. As noted in Rohmer et al. (2018), past research has suggested the replacement of meat and dairy consumption habits to decrease the environmental impact of our food production. For the above reasons consumers' attitudes towards dairy products is expected to change due to environmental or health concerns, a shift that is already taking place (Westhoek et al., 2014) and consumers seek replacements for their meat and dairy consumption (Finnegan, et al., 2018). Consequently, their preference for plant based dairy alternatives has been increasing (Rozenberg et al., 2016).

Although there are several studies regarding consumer behavior on dairy products internationally, only a few have focused on novel dairy products in the Balkan region. In addition, to the best of our knowledge, this is time that consumers' purchase intentions regarding novel dairy products in Greece and Serbia are examined.

The primary objective of this research is to investigate consumers' purchase intentions towards novel dairy products in Greece and Serbia using the Theory of Planned Behavior (TPB) as a theoretical framework. We decided to focus on these two specific countries for a number of reasons. First, there are several cultural, historical and religious similarities. Both countries have similar scores in most of Hofstede's cultural dimensions (hofstede-insights.com), while approximately $95 \%$ of their population is Christian Orthodox. Second, according to Brankov et al. (2019), there are considerable similarities among the two countries such as the taxation system's development and institutions (Tuncer, 2017). Additionally, both countries have experienced a severe economic crisis during the last years. It is worth mentioning that there is limited research available on nutritional changes in countries affected by economic transitions, wars, disintegration and political crisis (Ivanova et al., 2006).

The remaining sections of this paper are organized in the following order. First, a brief theoretical background of TPB is discussed and the proposed research model is presented. Next, ten research hypotheses regarding the impact of various factors on Serbian and Greek consumers' purchase intentions towards novel dairy products are developed. Moreover, the methodology and the results are presented and discussed. The paper ends with the conclusion and some thoughts on future research. 


\section{Theoretical background and hypotheses development}

\subsection{Theory of Planned Behavior Model}

According to Ajzen (1991), the Theory of Planned Behavior (TPB) model can be applied to predict consumers' behavior at the precise period and place of the research. TPB is one of the most commonly used models for the examination of social and healthrelated behavior (Ajzen, 2011; Thompson-Leduc et al., 2015). It contains three constructs which determine an individual's intention to perform a particular behavior: Attitude (the extent of rational and emotional favorability to perform a behavior), subjective norm (social pressures) and perceived behavioral control (perceived ease or difficulty to perform a behavior, as well as anticipated obstacles) (Godin et al., 2008). The proposed research model is illustrated in Figure 1.

Figure 1: Proposed research model on Serbian and Greek consumers' purchase intentions towards novel dairy products

(Adapted by: Ajzen, 1991)

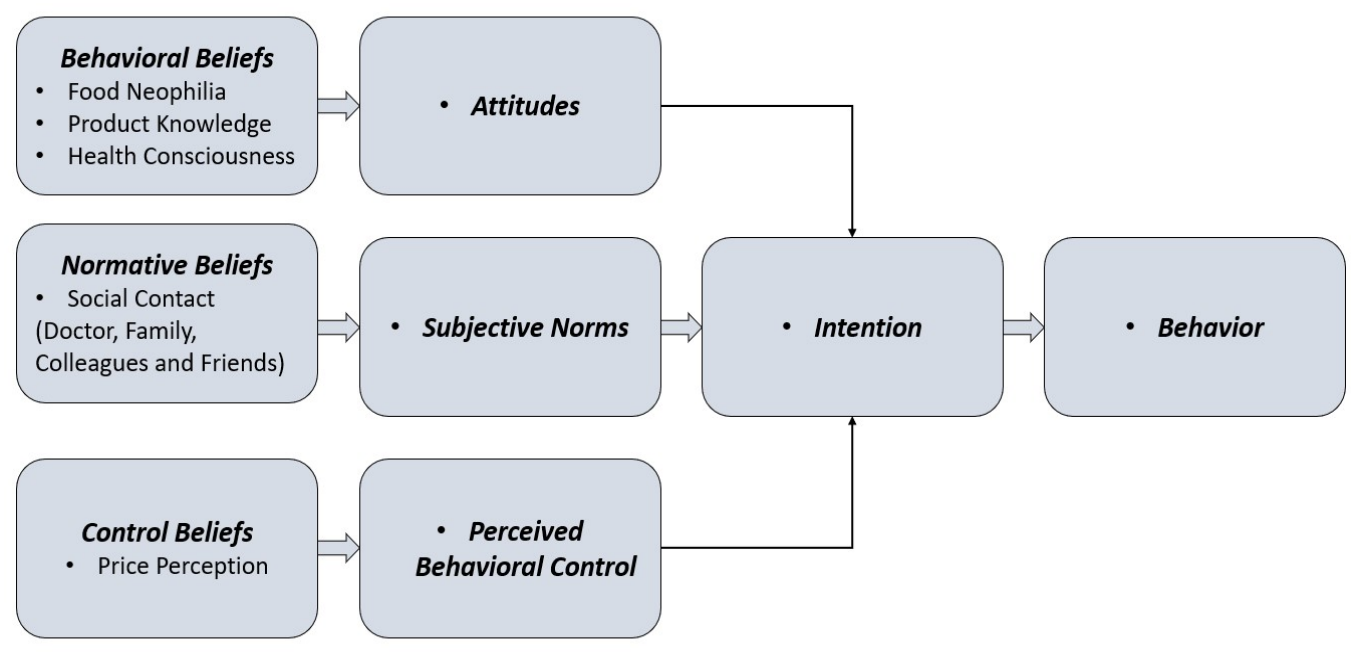

\subsection{Hypotheses Development}

\subsubsection{Food Neophilia}

Food neophilia has an important impact on consumers' purchase intentions regarding food products (Hall et al., 2004). Capiola and Raundenbush (2012), defined as food neophiliacs the individuals with an interest to try and explore new food products. Sumarjan et al. (2013) defined food neophilia as individuals' behavioral tendency to try and explore novel foods. Food neophiles can also be described as adventurous eaters (Wilk, 2008). 
Food neophilia may affect consumer purchase intentions differently due to variations in cultures and people's inclinations to explore alternative food products (Pelchat and Pliner, 1995). According to Cazacu (2012), there is no significant impact of consumers' food neophilia on their purchase intentions of dairy functional products in Greece. However, the findings of Kichukova et al. (2017), indicate a positive effect of Greek consumers' food neophilia on their purchase intentions towards food and beverage products containing aloe vera. Therefore, it is hypothesized that:

H1a) Food neophilia among Serbian consumers will have a positive impact on their purchase intentions towards novel dairy products.

H1b) Food neophilia among Greek consumers will have a positive impact on their purchase intentions towards novel dairy products.

\subsubsection{Product Knowledge}

Possession of knowledge towards products can facilitate consumers' decisions and influence their perceptions directly or indirectly and affect their final buying decision (Shirin and Kambiz, 2011). Product knowledge refers to information gathered and stored in consumer's memory about already used products. Consumers, prior of making a purchase, ask themselves why they are buying a specific product, where they are buying it from and when they are buying it (Sharma et al., 2013). Cazacu et al. (2014) and Kichukova et al. (2017) have found that Greek consumers' purchase intentions have been positively influenced from product knowledge. Thus, it is hypothesized that:

H2a) Product knowledge will have a positive impact on Serbian consumers' purchase intentions towards novel dairy products.

H2b) Product knowledge will have a positive impact on Greek consumers' purchase intentions towards novel dairy products.

\subsubsection{Health Consciousness}

Traditionally, dairy products are regarded as high-quality products and a great source of nutrients (Bozoglu et al., 2014; Rozenberg, et al., 2016). However, there are concerns that they may negatively impact human health (Cash et al., 2005). Yap and Othman (2010) stated that, from a marketing perspective, healthy lifestyle is related to consumers' food consumption orientation. Consequently, consumers' interests, activities and beliefs towards the consumption of wellness-related products and beverages define their healthy lifestyle nutrition activities. Nowadays, people's demand for healthy lifestyle and concerns among societies towards health-related issues, are increasing. Thus, it is expected that this health consciousness will positively impact the consumers' purchase intentions towards novel dairy products. Therefore, we hypothesize that:

H3a) Health consciousness will have a positive impact on Serbian consumers' purchase intention purchase towards novel dairy products. 


\section{H3b) Health consciousness will have a positive impact on Greek consumers' purchase intention purchase towards novel dairy products.}

\subsubsection{Social Contacts}

Social contacts nowadays are influenced by the interaction of people in social media and their opinion sharing towards food products and healthy lifestyles. Dahl (2013) defined social contacts as an interaction among people regarding the sharing of their opinions, emotions or behaviors towards product consumption. Social influence may have an effect on consumers' purchase intentions regarding the consumption of food products. Consumers may be influenced by the groups of friends, family, doctor, other consumers and social concerns.

Specific dairy product preferences and perceptions among consumers may depend substantially from the demographic and geographic position of the countries (Kumar and Babu, 2014). Cazacu et al. (2014) found that social contacts positively influence Greek consumers' purchase intentions for water buffalo milk products. Kickukova et al. (2017) also found that the Greek consumers' social contacts have a positive impact on their purchase decisions towards food and beverage products containing aloe vera. Thus, it is hypothesized that:

H4a) Social contacts will have a positive impact on Serbian consumers' purchase intentions towards novel dairy products.

H4b) Social contacts will have a positive impact on Greek consumers' purchase intentions towards novel dairy products.

\subsubsection{Price Perception}

According to Lichtenstein et al. (1993), price is one of the most significant factors influencing consumer purchase intentions. Shepherd and Rats (2006) state that price is a leading component of consideration among consumers towards their buying choice. Price can predetermine purchasing decisions and may be used among consumers as an indicator for the quality of the products. Furthermore, consumers with high price consciousness, intend to spend less money on products (Lee, 2008).

In many cases novel dairy products are expected to be more expensive than the "conventional ones", as R\&D costs are included in addition to the relatively small production quantities produced compared to the "conventional ones". The price of functional dairy products is a barrier to consumers (Landström et al., 2009). So it logical to expect that "price sensitive" consumers may be more reluctant to purchase these products. Thus, we hypothesize that:

H5a) Price perception will have a negative impact on Serbian consumers' purchase intentions towards novel dairy products.

H5b) Price perception will have a negative impact on Greek consumers' purchase intentions towards novel dairy products. 


\section{Methodology}

The quantitative research method was applied in this research project as it allows to test pre-determined hypotheses and to generalize the results. The objective of this study is to examine the Serbian and the Greek consumers' purchase intentions towards novel dairy products. The application of the TPB method has been identified as an efficient research method to examine consumers' purchase intentions (Ajzen, 1991; Aramatunga et al., 2002). According to the TPB model, consumers' behavior is determined by three main factors: 1) behavioral beliefs (attitudes), 2) normative beliefs (subjective norms) and 3) control beliefs (perceived behavioral control). For the purposes of this study, different variables have been taken into consideration in order to analyze each factor and different constructs were selected for each variable. For the behavioral beliefs, the selected variables are: food neophilia, product knowledge and health consciousness as adapted from Verbeke (2005) and Urala and Lanteenmaki (2007). Moreover, for the normative beliefs, the variable social contacts is used, including doctor, family, colleagues and friends, adapted from Mitchell and Ring (2010). Finally, the selected variable for perceived behavioral control is price perception, with constructs adapted from Krystallis et al. (2008).

The research questionnaire was designed in the English language, taking into consideration the selected variables and constructs. Additionally, the Likert scale was applied (Lavrakas, 2008; Madu, 2003). The questionnaire was translated to the Serbian and Greek languages to facilitate respondents and to obtain more accurate responses. The collected responses were then translated to English. During a two-month period, 288 usable answers were collected.

\subsection{Sample Characteristics}

A total of 144 questionnaires were collected from Serbian respondents (75 females and 69 males). A total of 33\% of the respondents were between 21-35 years of age, another $33 \%$ between $36-50$ years, followed by $22 \%$ under 21 years, while $13 \%$ of them are aged between $50-75$ years and only $1 \%$ was older than 75 years. Nearly $50 \%$ of the survey participants from Serbia stated that they have an Undergraduate BSc degree, followed by $37 \%$ with a High school degree. Additionally, $11 \%$ of the respondents have a Graduate MSc degree, while 6\% a PhD- doctorate degree.

The questionnaire survey conducted in Greece resulted in 144 respondents (77 females and 67 males). The Greek sample survey included mostly individuals between 2135 years (40\%) of age, followed by $32 \%$ under 21 and $19 \%$ betweed $35-50$ years of age. In regards to education, most of the survey participants hold an Undergraduate BSc degree $(53 \%)$, a total of $23 \%$ a High School degree, participants with Graduate MSc degree represent $15 \%$ of the sample and the ones with a $\mathrm{PhD}$-doctorate degree the remaining $9 \%$.

\section{Results}

Prior to hypotheses testing, a reliability and validity check was applied to both samples. Factor analysis was used in order to control for validity and to reduce the data to 
principal components. As most of the loadings were above .700 , the validity (accuracy) of the measures used in the questionnaire is confirmed. The Cronbach's alpha test was applied in order to examine for reliability of the question sets. In most questions, the results indicated a relatively good level of internal consistency for the scales.

\subsection{Correlations (Serbia)}

Table 1: Kendall's tau-b Test: Purchase Intention - Food Neophilia (Serbian data)

Correlations

\begin{tabular}{|lll|l|l|}
\hline & & $\begin{array}{l}\text { Purchase } \\
\text { Intention }\end{array}$ & Food Neophilia \\
\hline Kendall's tau_b & Purchase Intention & Correlation Coefficient & 1.000 & $.296^{* *}$ \\
& Sig. (2-tailed) &. & .000 \\
& $\mathrm{~N}$ & 432 & 432 \\
\cline { 2 - 5 } & Food Neophilia & Correlation Coefficient & $.296^{* *}$ & 1.000 \\
& Sig. (2-tailed) & .000 &. \\
& $\mathrm{~N}$ & 432 & 864 \\
\hline
\end{tabular}

**. Correlation is significant at the 0.01 level (2-tailed).

In regards to the correlation between food neophilia and purchase intention of the Serbian sample, the coefficient is .296 and the p-value is .000. Based on the results, $\mathbf{H 1 a}$ is confirmed.

Table 2: Kendall's tau-b Test: Purchase Intention - Product Knowledge (Serbian data)

Correlations

\begin{tabular}{|lll|l|l|}
\hline & & $\begin{array}{l}\text { Purchase } \\
\text { Intention }\end{array}$ & $\begin{array}{l}\text { Product } \\
\text { Knowledge }\end{array}$ \\
\hline Kendall's tau_b & Purchase Intention & Correlation Coefficient & 1.000 & $.178^{* *}$ \\
& Sig. (2-tailed) &. & .000 \\
& $\mathrm{~N}$ & 432 & 432 \\
\cline { 2 - 5 } & Product Knowledge & Correlation Coefficient & $.178^{* *}$ & 1.000 \\
& Sig. (2-tailed) & .000 &. \\
& $\mathrm{~N}$ & 432 & 432 \\
\hline
\end{tabular}

${ }^{* *}$. Correlation is significant at the 0.01 level (2-tailed).

The correlation between product knowledge and purchase intention is positive and weak. The correlation value is .178 and the $p$ value is .000 . Therefore, $\mathbf{H 2 a}$ is supported. 
Table 3: Kendall's tau-b Test: Purchase Intention - Health Consciousness (Serbian data)

Correlations

\begin{tabular}{|c|c|c|c|c|}
\hline & & & $\begin{array}{l}\text { Purchase } \\
\text { Intention }\end{array}$ & $\begin{array}{l}\text { Health } \\
\text { Consciousness }\end{array}$ \\
\hline \multirow[t]{2}{*}{ Kendall's tau_b } & Purchase Intention & $\begin{array}{l}\text { Correlation Coefficient } \\
\text { Sig. (2-tailed) } \\
\mathrm{N}\end{array}$ & $\begin{array}{l}1.000 \\
432\end{array}$ & $\begin{array}{l}.132^{* *} \\
.002 \\
432\end{array}$ \\
\hline & $\begin{array}{l}\text { Health } \\
\text { Consciousness }\end{array}$ & $\begin{array}{l}\text { Correlation Coefficient } \\
\text { Sig. (2-tailed) } \\
\mathrm{N}\end{array}$ & $\begin{array}{l}.132^{* *} \\
.002 \\
432\end{array}$ & $\begin{array}{l}1.000 \\
432\end{array}$ \\
\hline
\end{tabular}

**. Correlation is significant at the 0.01 level (2-tailed).

Regarding the correlation between health consciousness and purchase intention of the Serbian consumers, the coefficient is .132 while the $p$ value is .002 . Hence, $\mathbf{H} 3 \mathbf{a}$ is confirmed.

Table 4: Kendall's tau-b Test: Purchase Intention - Social Contacts (Serbian data)

Correlations

\begin{tabular}{|lll|l|l|}
\hline & & $\begin{array}{l}\text { Purchase } \\
\text { Intention }\end{array}$ & Social Contacts \\
\hline Kendall's tau_b & Purchase Intention & Correlation Coefficient \\
& Sig. (2-tailed) & 1.000 & $.143^{* *}$ \\
& $\mathrm{~N}$ &. & .001 \\
& & Correlation Coefficient & $.143^{* *}$ & 432 \\
\cline { 2 - 5 } & Social Contacts & .001 & 1.000 \\
& $\mathrm{~N}$ & 432 &. \\
& & & 432 \\
\hline
\end{tabular}

**. Correlation is significant at the 0.01 level (2-tailed).

The results indicate a positive impact of social contacts on the Serbian consumers' purchase intention, as the correlation coefficient is .143 and the p-value is .001. Thus, H4a is supported.

Table 5: Kendall's tau-b Test: Purchase Intention - Price Perception (Serbian data)

Correlations

\begin{tabular}{|c|c|c|c|c|}
\hline & & & $\begin{array}{l}\text { Purchase } \\
\text { Intention }\end{array}$ & \begin{tabular}{|l} 
Price \\
Perception
\end{tabular} \\
\hline \multirow[t]{2}{*}{$\begin{array}{l}\text { Kendall's } \\
\text { tau_b }\end{array}$} & Purchase Intention & $\begin{array}{l}\text { Correlation } \\
\text { Coefficient } \\
\text { Sig. (2-tailed) } \\
\text { N }\end{array}$ & $\begin{array}{l}1.000 \\
. \\
432\end{array}$ & $\begin{array}{l}.430^{* *} \\
.000 \\
432\end{array}$ \\
\hline & Price Perception & $\begin{array}{l}\text { Correlation } \\
\text { Coefficient } \\
\text { Sig. (2-tailed) } \\
\text { N }\end{array}$ & $\begin{array}{l}.430^{* *} \\
.000 \\
432\end{array}$ & $\begin{array}{l}1.000 \\
432\end{array}$ \\
\hline
\end{tabular}

**. Correlation is significant at the 0.01 level (2-tailed). 
In regards to the correlation between price perception and purchase intention, the correlation coefficient is .430 and the p-value is .000 , indicating a positive impact. Therefore, $\mathrm{H} 5 \mathrm{a}$ is confirmed.

\subsection{Correlations (Greece)}

Table 6: Kendall's tau-b Test: Purchase Intention - Food Neophilia (Greek data)

\begin{tabular}{|c|c|c|c|c|}
\hline & & & $\begin{array}{l}\text { Purchase } \\
\text { Intention }\end{array}$ & $\begin{array}{l}\text { Food } \\
\text { Neophilia }\end{array}$ \\
\hline \multirow[t]{2}{*}{ Kendall's tau_b } & Purchase Intention & $\begin{array}{l}\text { Correlation } \\
\text { Coefficient } \\
\text { Sig. (2-tailed) } \\
\mathrm{N}\end{array}$ & $\begin{array}{l}1.000 \\
432 \\
\end{array}$ & $\begin{array}{l}.048 \\
.227 \\
432 \\
\end{array}$ \\
\hline & Food Neophilia & $\begin{array}{l}\text { Correlation } \\
\text { Coefficient } \\
\text { Sig. (2-tailed) } \\
\mathrm{N}\end{array}$ & $\begin{array}{l}.048 \\
.227 \\
432\end{array}$ & $\begin{array}{l}1.000 \\
864\end{array}$ \\
\hline
\end{tabular}

As shown in Table 6, the correlation coefficient among food neophilia and purchase intention is .048 while the p-value is .227 (larger than 0.05 ). Hence, H1b is not supported.

Table 7: Kendall's tau-b Test: Purchase Intention - Product Knowledge (Greek data)

\begin{tabular}{|c|c|c|c|c|}
\hline & & & $\begin{array}{l}\text { Purchase } \\
\text { Intention }\end{array}$ & $\begin{array}{l}\text { Product } \\
\text { Knowledge }\end{array}$ \\
\hline \multirow[t]{2}{*}{$\begin{array}{l}\text { Kendall's } \\
\text { tau_b }\end{array}$} & Purchase Intention & $\begin{array}{l}\text { Correlation Coefficient } \\
\text { Sig. (2-tailed) } \\
\mathrm{N}\end{array}$ & $\begin{array}{l}1.000 \\
432\end{array}$ & $\begin{array}{l}.038 \\
.339 \\
432 \\
\end{array}$ \\
\hline & Product Knowledge & $\begin{array}{l}\text { Correlation Coefficient } \\
\text { Sig. (2-tailed) } \\
\mathrm{N}\end{array}$ & $\begin{array}{l}.038 \\
.339 \\
432\end{array}$ & $\begin{array}{l}1.000 \\
432\end{array}$ \\
\hline
\end{tabular}

In regards to product knowledge and purchase intention, the correlation coefficient is .038 , indicating a very weak correlation. In addition, the p-value is .339 (larger than $0.05)$, thus $\mathbf{H} \mathbf{2 b}$ is not confirmed. 
Table 8: Kendall's tau-b Test: Purchase Intention - Health Consciousness (Greek data)

Correlations

\begin{tabular}{|c|c|c|c|c|}
\hline & & & $\begin{array}{l}\text { Purchase } \\
\text { Intention }\end{array}$ & $\begin{array}{l}\text { Health } \\
\text { Consciousness }\end{array}$ \\
\hline \multirow[t]{2}{*}{$\begin{array}{l}\text { Kendall's } \\
\text { tau_b }\end{array}$} & Purchase Intention & $\begin{array}{l}\text { Correlation } \\
\text { Coefficient } \\
\text { Sig. (2-tailed) } \\
\mathrm{N}\end{array}$ & $\begin{array}{l}1.000 \\
\cdot \\
432\end{array}$ & $\begin{array}{l}.149^{* *} \\
.000 \\
432\end{array}$ \\
\hline & Health Consciousness & $\begin{array}{l}\text { Correlation } \\
\text { Coefficient } \\
\text { Sig. (2-tailed) } \\
\mathrm{N}\end{array}$ & $\begin{array}{l}.149^{* *} \\
.000 \\
432\end{array}$ & $\begin{array}{l}1.000 \\
432\end{array}$ \\
\hline
\end{tabular}

**. Correlation is significant at the 0.01 level (2-tailed).

Considering health consciousness and purchase intention, the correlation coefficient is .149 and the $p$-value is .000 , indicating a positive but weak relationship. Therefore, $\mathbf{H} 3 \mathbf{b}$ is supported.

Table 9: Kendall's tau-b Test: Purchase Intention - Social Contacts (Greek data)

Correlations

\begin{tabular}{|c|c|c|c|c|}
\hline & & & $\begin{array}{l}\text { Purchase } \\
\text { Intention }\end{array}$ & Social Contacts \\
\hline \multirow[t]{2}{*}{ Kendall's tau_b } & Purchase Intention & $\begin{array}{l}\text { Correlation } \\
\text { Coefficient } \\
\text { Sig. (2-tailed) } \\
\mathrm{N}\end{array}$ & $\begin{array}{l}1.000 \\
\cdot \\
432\end{array}$ & $\begin{array}{l}.025 \\
.525 \\
432\end{array}$ \\
\hline & Social Contacts & $\begin{array}{l}\text { Correlation } \\
\text { Coefficient } \\
\text { Sig. (2-tailed) } \\
\text { N }\end{array}$ & $\begin{array}{l}.025 \\
.525 \\
432\end{array}$ & $\begin{array}{l}1.000 \\
432\end{array}$ \\
\hline
\end{tabular}

The results of social contacts and the Greek consumers' purchase intention show no statistically significant relationship, as the correlation coefficient is 0.25 and the p-value is .525 (more than 0.05 ). Based on the results, $\mathbf{H} 4 \mathrm{~b}$ is not confirmed.

Table 10: Kendall's tau-b Test: Purchase Intention - Price Perception (Greek data) Correlations

\begin{tabular}{|lll|l|l|}
\hline & & $\begin{array}{l}\text { Purchase } \\
\text { Intention }\end{array}$ & Price Perception \\
\hline Kendall's tau_b & Purchase Intention & $\begin{array}{l}\text { Correlation } \\
\text { Coefficient } \\
\text { Sig. (2-tailed) } \\
\text { N }\end{array}$ & 1.000 & $.177^{* *}$ \\
& & .732 & .000 \\
& Price Perception & $\begin{array}{l}\text { Correlation } \\
\text { Coefficient } \\
\text { Sig. (2-tailed) }\end{array}$ & $.177^{* *}$ & 1.000 \\
& $\mathrm{~N}$ & .000 &. \\
& & 432 & 576 \\
\hline
\end{tabular}

**. Correlation is significant at the 0.01 level (2-tailed). 
Finally, in regards to price perception and purchase intention, the correlation coefficient is .177 , and the p-value is 0.00 , indicating a weak but statistically significant relationship. Thus, $\mathbf{H} \mathbf{5 b}$ is supported.

\section{Discussion}

According to Chatellier (2017), the small decrease in demand for dairy products in the EU, and the steep increase in production has created a challenge for the industry and puts pressure, among others, to supply the market with a greater variety of dairy products. Furthermore, there are increasing concerns about the consumption of livestock products, due, among others, to ethical and environmental concerns. A recent research by Westhoek et al. (2014) shows that a decrease of livestock product consumption, including dairy products, will have a positive impact on the environment and will benefit consumers' health. Thus, there is greater pressure to the industry to explore and understand the purchase intentions of consumers regarding novel dairy products to address the current challenges.

More specifically, in regards to consumers' purchase intentions of novel dairy products and food neophilia, $\mathrm{H} 1 \mathrm{a}$ is accepted while $\mathrm{H} 1 \mathrm{~b}$ is not. The attitude towards novel dairy products does have an impact on the Serbian consumers' intention to buy novel food products, while it does not in the case of the Greek consumers. The latter is in line with Cazacu's (2012) results who did not find a relationship between neophilia and dairy functional foods. The similar findings indicate that Greek consumers demonstrate a consistent intention towards novel dairy products over these years.

In respect to $\mathrm{H} 2$ (purchase intention and product knowledge) the results indicate that knowledge about the product has a positive impact on purchase intentions of the Serbian consumers. This result is in accordance with the findings of previous studies on novel food products (Cazacu et al., 2014; Kichukova et al., 2017). However, knowledge about novel dairy products does not appear to have an impact on the Greek consumers' intentions to purchase such products.

As far as the impact of health consciousness on consumers' purchase intentions (H3a \& H3b), consumers' purchase intentions in both countries are positively affected by the products health awareness. As Bhat and Bhat (2011) note dairy products are well known for their health benefits since medieval times and today, more than ever, offer many opportunities for development in the functional food sector. Rahnama and Rajabpour (2017), in their study on consumer choices of dairy products in Iran, also found that functional values (including health) have a positive impact on consumer purchases of these products. As they note, their finding is similar to previous research results (Ares et al., 2010).

Interestingly, social contacts do not appear to influence consumers' purchase intentions in Greece, contrary to Serbia. Serbian consumers are affected by their social contacts in their intentions to purchase novel dairy products, while consumers from Greece are not ( $\mathrm{H} 4 \mathrm{a}$ and $\mathrm{H} 4 \mathrm{~b})$. A similar research by Rahnama and Rajbpoor (2017) found that social values have a positive impact on dairy products consumption, among Iranian consumers. Moreover, Nolan-Clark et al. (2011) showed that family purchasing habits and preferences for dairy products have an influence on their consumption. According to Lu et 
al. (2010), individuals in collectivistic societies have the tendency to follow social values and norms closely (Hofstede, 1983) in order to gain and maintain acceptance by their social group. Both Greece and Serbia are considered as collectivist cultures, so it was expected that consumers in both countries will be affected in regards to their purchase intentions of novel products by their social contacts.

Lastly, according to the findings, higher prices of novel dairy products have a negative impact on consumers purchase intentions in both countries ( $\mathrm{H} 5 \mathrm{a}$ and $\mathrm{H} 5 \mathrm{~b}$ ). This is in accordance with the ones of Davis et al. (2011) in their study of 16 different categories of dairy products. The researchers found that price affects the purchasing decision of US consumers. Nolan-Clark et al. (2011) also found that the high cost to perceived benefit of functional dairy products could impede their consumption. This is in line with Armstrong et al. (2005) who found that the cost of functional or health enhancing dairy products affected consumers in Northern Ireland as only $35 \%$ of survey respondents were feeling satisfied with the price of such products. Similarly, Rahnama and Rajabpour (2017) showed that price has a significant impact on consumer purchases of these products. Furthermore, according to the same researchers, the impact of price is the most important functional value to Iranian consumers.

\section{Conclusion}

The purpose of this study was to examine consumers' purchase intentions towards novel dairy products with evidence from Greece and Serbia. To the best of our knowledge, although there are numerous research papers on consumers' purchase intentions towards novel dairy food products, only a few have examined this issue among countries and in this specific region. Additionally, there are no similar previous studies that examine consumers' intentions between Greece and Serbia. Furthermore, the gender, age and educational level balance among the respondents from the two countries in this research, allow for a more meaningful comparison on consumers' intentions.

The results can be beneficial for marketing companies in order to develop better marketing strategies which will attract consumers' intention to purchase novel dairy products. Additionally, the research findings can assist the dairy manufacturing companies to focus on consumer preferences and develop new products which will be successful in the future market.

In regards to future research, although the demand for functional foods appears to be heterogeneous throughout different countries (Vicentini et al., 2016), the noticeable differences found in this research (food neophilia, product knowledge and social contacts) set the ground for future research. Additionally, a larger sample size in both countries is needed to enable for the generalization of results (Comrey \& Lee, 2013).

Acknowledgment: The present study has been presented at the $12^{\text {th }}$ International Conference "Economies of the Balkan and Eastern European Countries", EBEEC 2020, that has been online in Opatija, Croatia from May $29^{\text {th }}$ to $31^{\text {th }} 2020$ (http://ebeec.ihu.gr/). 


\section{References}

Ajzen, I. (1991). The theory of planned behavior. Organizational Behavior and Human Decision Processes, Vol. 50 No. 2, pp. 179-211.

Ajzen, I. (2011). The Theory of Planned Behavior: reactions and reflections. Psychology \& Health, Vol. 26 No. 9, pp. 1113-1127.

Amaratunga, D., Baldry, D., Sarshar, M. \& Newton, R. (2002). Quantitative and Qualitative Research in the Built Environment: Application of "Mixed Research Approach. Work Study, Vol. 51 No. 1, pp. 17-31.

Armstrong, G., Farley, H., Gray, J. \& Durkin, M. (2005). Marketing health-enhancing foods: implications from the dairy sector. Marketing Intelligence \& Planning, Vol. 23 No. 7, pp. 705719 .

Bhat, Z.F. \& Bhat, H. (2011). Milk and dairy products as functional foods: a review. International Journal of Dairy Science, Vol. 6 No. 1, pp. 1-12.

Bozoglou, M., Huang, C.L., Florkowski, W. \& Topuz, B.K. (2014). Consumers' purchase intention toward safety labeled dairy products in the Black Sea region of Turkey. Journal of Agricultural Sciences, Vol. 20 No. 4, pp. 434-445.

Brankov, T., Markopoulos, T. \& Kontakos, S. (2019). Long-term trends in food consumption: comparison between Serbia and Greece. Economics of Agriculture, Vol. 66 No. 4, pp. 975988.

Bryman, A. \& Cramer, D. (2005). Quantitative Data Analysis with SPSS 12 and 13: A Guide for Social Scientists. Routledge, Psychology Press.

Capiola, A. \& Raudenbus, B. (2012). Physiological Responses of Food Neophobics and Food Neophilics to Food and Non-Food Stimuli. Apetite, Vol. 58 No. 3, pp. 1106-1108.

Cash, S.B., Wang, C. \& Goddard, E.W. (2005). Dairy products and consumer demand for health foods. Advances in Dairy Technology, 17, pp. 67-80.

Cazacu, S. (2012). Greek Consumers' Purchase Intentions towards Dairy Functional Foods. MSc thesis, International Hellenic University.

Cazacu, S., Rotsios, K. \& Moshonas, G. (2014). Consumers' purchase intentions towards Water Buffalo Milk Products (WBMPs) in the greater area of Thessaloniki, Greece. Procedia Economics and Finance, Vol. 9, pp. 407-416.

Cerjak, M. \& Tomić, M. (2015). Buying motives and trust of young consumers for functional fermented dairy Products: Evidence from Croatian students. Journal of International Food \& Agribusiness Marketing, Vol. 27 No. 3, pp. 177-187.

Chatellier, V. (2017). International, European and French trade in dairy products: trends and competitive dynamics. INRA Productions Animales, Vol. 17 No. 5, pp. 143-162.

Comrey, A.L. \& Lee, H.B. (2013). A First Course in Factor Analysis. 2nd edition, Hillsdale: Psychology Press.

Dahl, D. (2013). Social influence and consumer behavior. Journal of Consumer Research, Vol. 40 No. 2, pp. 3-5.

Dror, D.K. \& Allen, L.H. (2014). Dairy product intake in children and adolescents in developed countries: Trends, nutritional contribution, and a review of association with health outcomes. Nutrition Reviews, Vol. 72 No. 2, pp. 68-81.

Finnegan, W., Goggins, J. \& Zhan, X. (2018). Assessing the environmental impact of the dairy processing industry in the Republic of Ireland. Journal of Dairy Research, Vol. 85 No. 3, pp. 396-399. 
Godin, G., Bélanger-Gravel, A., Eccles, M. \& Grimshaw, J. (2008). Healthcare professionals' intentions and behaviours: A systematic review of studies based on social cognitive theories. Implementation Science, Vol. 3 No. 1, pp. 36.

Gulland, A. (2017). Dietary Guidelines Should Encourage a Healthy Planet. British Medical Journal (Online) 356: J1254, https://doi.org/10.1136/bmj.j1254

Hall, C.M., Sharples, L., Mitchell, R., Macionis, N. \& Cambourne, B. (2004). Food tourism around the world. Routledge.

Hofstede, G. (1980). Culture's consequences-international differences in work-related values. Beverly Hills, London: Sage Publications.

Hofstede, G. (1983). The cultural relativity of organizational practices and theories. Journal of International Business Studies, Vol. 14 No. 2, pp. 75-89.

Ivanova L., Dimitrov P., Ovcharova D., Dellava J. \& Hoffman D.J. (2006). Economic transition and household food consumption: a study of Bulgaria from 1985 to 2002. Economics \& Human Biology, Vol. 4 No. 3, pp. 383-397.

Jones, V.S., Drake, M.A., Harding, R. \& Kuhn-Sherlock, B. (2008). Consumer perception of soy and dairy products: A cross-cultural study. Journal of Sensory Studies, Vol. 23 No. 1, pp. 65-79.

Kichukova, T., Sklavounos, N. \& Rotsios, K. (2017). Food and beverage products containing aloe vera: evidence from the Greek market. Journal of Business Paradigms, Vol. 2 No. 2, pp. 6287.

Krystallis, A., Maglaras, G. \& Mamalis, S. (2008). Motivations and Cognitive Structures of Consumers in their Purchasing of Functional Foods. Food Quality and Preference, Vol. 19 No. 1, pp. 525-538.

Kumar, A.A. \& Babu, S. (2014). Factors influencing consumer buying behavior with special reference to dairy products in Pondicherry state. International Monthly Refereed Journal of Research in Management and Technology, Vol. 3 No. 1, pp. 65-73.

Landström, E., Hursti, U.K.K. \& Magnusson, M. (2009). Functional foods compensate for an unhealthy lifestyle. Some Swedish consumers' impressions and perceived need of functional foods. Appetite, Vol. 53 No.1, pp. 34-43.

Lavrakas, P.J. (2008). Encyclopedia of Survey Research Methods, SAGE Publications, Thousand Oaks, California, USA.

Lee, C.H. (2008). The Effects of Price Consciousness, Brand Consciousness and Familiarity on Store Brand Purchase Intention. Management Review, Vol. 27(3), pp. 21-40.

Lichtenstein, D.R., Ridgway, N.M. \& Netemeyer, R.G. (1993). Price Perceptions and Consumer Shopping Behaviour: A Field Study. Journal of Marketing Research, Vol. 30 No. 2, pp. 234245.

Lu, H., Hou, H., Dzwo, T., Wu, Y., Andrews, J.E., Weng, S., Lin, M. \& Lu, J. (2010). Factors influencing intentions to take precautions to avoid consuming food containing dairy products: Expanding the theory of planned behaviour. British Food Journal, Vol. 112 No. 9, pp. 919933.

Madu, C. (2003). Statistics as Easy as 1, 2, 3 with Microsoft Excel for Windows. Chi Publishers, Fairfield, CT.

Mitchell, C. \& Ring, E. (2010). Swedish Consumers' Attitudes and Purchase Intentions of Functional Food: A study based on the Theory of Planned Behaviour. Master thesis, Umeå University, Faculty of Social Sciences, Umeå School of Business, retrieved from:http://www.divaportal.org/smash/record.jsf?pid=diva2\%3A327547\&dswid=-8024 
Nolan-Clark, D. J., Neale, E. P., Probst, Y. C., Charlton, K. E. \& Tapsell, L. C. (2011). Consumers' salient beliefs regarding dairy products in the functional food era: a qualitative study using concepts from the theory of planned behaviour. BMC Public Health, 11(1), 843.

Özer, B.H. \& Kirmaci, H.A. (2010). Functional milks and dairy beverages. International Journal of Dairy Technology, Vol. 63 No. 1, pp. 1-15.

Pelchat, M.L. \& Pliner, P. (1995). "Try it. You'll like it". Effects of information on willingness to try novel foods. Appetite, Vol. 24 No. 2, pp. 153-165.

Rahnama, H. \& Rajabpour, S. (2017). Factors for consumer choice of dairy products in Iran. Appetite, 111, pp. 46-55.

Rohmer, S.U.K., Gerdessen, J.C., Claassen, G.D. H., Bloemhof, J.M. \& van't Veer, P. (2018). A nutritional comparison and production perspective: Reducing the environmental footprint of the future. Journal of Cleaner Production, Vol. 196, pp. 1407-1417.

Rozenberg, S. et al., (2016). Effects of dairy products consumption on health: benefits and beliefs-a commentary from the Belgian Bone Club and the European Society for Clinical and Economic Aspects of Osteoporosis, Osteoarthritis and Musculoskeletal Diseases. Calcified tissue international, Vol. 98 No. 1, pp. 1-17.

Shirin, K. \& Kambiz, H.H. (2011). The effect of the country-of-origin image, product knowledge and product involvement on consumer purchase decisions. Chinese Business Review, Vol. 10 No. 8, pp. 601-615.

Samoggia, A. (2016). Healthy Food: Determinants of price knowledge of functional dairy products. Journal of Food Products Marketing, Vol. 22 No. 8, pp. 905-929.

Sanders, K.M., Nowson, C.A., Kotowicz, M.A., Briffa, K., Devine, A. \& Reid, I.R. (2009). Calcium and bone health: Position statement for the Australian and New Zealand bone and mineral society, osteoporosis Australia and the endocrine society of Australia. Medical Journal of Australia, Vol. 190 No. 6, pp. 316-320.

Sharma, P., Sivakumaran, B. \& Marshall, R. (2013). Exploring impulse buying in services: toward an integrative framework. Journal of the Academy of Marketing Science, Vol. 42 No. 2, pp. 154170.

Shepherd, R. \& Raats, M. (2006). The psychology of food choice (Vol. 3). CABI, Oxfordshire, UK.

Sumarjan, N. et al. (2013). Hospitality and Tourism: Synergizing Creativity and Innovation in Research. CRC Press, Florida, USA.

Tempesta, T. \& Vecchiato, D. (2013). An analysis of the territorial factors affecting milk purchase in Italy. Food Quality and Preference, Vol. 27 No. 1, pp. 35-43.

Thompson-Leduc, P., Clayman, M.L., Turcotte, S. \& Légaré, F. (2015). Shared decision-making behaviours in health professionals: a systematic review of studies based on the Theory of Planned Behaviour. Health Expectations, Vol. 18 No. 5, pp. 754-774.

Thorning, T.K., Raben, A., Tholstrup, T., Soedamah-Muthu, S.S., Givens, I. \& Astrup, A. (2016). Milk and dairy products: good or bad for human health? An assessment of the totality of scientific evidence. Food \& nutrition research, Vol. 60 No. 1, 32527.

Tuncer, A.C. (2017). Conditionality, Fiscal Rules and International Financial Control in the European Periphery before 1914. In: Cardinale, I., Scazzieri, R. (Eds.). The political economy of the Eurozone. Cambridge University Press, Cambridge, pp. 96-129.

Urala, N. \& Lähteenmäki, L. (2007). Consumers Changing Attitudes Towards Functional Foods. Food Quality and Preference, Vol. 18 No. 1, pp. 1-12.

Verbeke, W. (2005). Consumer Acceptance of Functional Foods: Socio-Demographic, Cognitive and Attitudinal Determinants. Food Quality and Preference, Vol. 16 No. 1, pp. 45-57. 
Vicentini, A., Liberatore, L. \& Mastrocola, D. (2016). Functional Foods: Trends and Development of the Global Market. Italian Journal of Food Science, Vol. 28 No. 2, pp. 338-351.

Westhoek, H., Lesschen, J.P., Rood, T., Wagner, S., De Marco, A., Murphy-Bokern, D., Leip, A., van Grinsven, H., Sutton, M.A. \& Oenema, O. (2014). Food choices, health and environment: effects of cutting Europe's meat and dairy intake. Global Environmental Change, Vol. 26, pp. 196-205.

Wilk, R. (2008). Hate/love for foreign food: Neophilia, neophobia and globalization. Critique and Humanism, Vol. 25 No. 1, pp. 65-78.

Yap, S.F. \& Othman, M.N. (2010). Marketing to healthy lifestyle consumers: an analysis of demographic and social cognitive factors. Asia Pacific Management Review, Vol. 15 No. 4, pp. 601-618. 